Sari Pediatri, Vol. 7, No. 2, September 2005: 77 - 84

\title{
Obstructive sleep apnea syndrome pada Anak
}

\author{
Bambang Supriyatno, Rusmala Deviani
}

\begin{abstract}
Obstructive Sleep Apnea Syndrome (OSAS) adalah suatu sindrom obstruksi total atau parsial jalan nafas yang menyebabkan gangguan fisiologis yang bermakna dengan dampak klinis yang bervariasi. Prevalensi OSAS adalah 0,7 - 10,3\%. Beberapa keadaan dapat merupakan faktor risiko OSAS seperti hipertofi adenoid dan atau tonsil, obesitas, disproporsi sefalometri, kelainan daerah hidung. OSAS pada anak berbeda dengan dewasa baik faktor risiko maupun tata laksananya. Manifestasi klinis OSAS pada anak adalah kesulitan bernafas pada saat tidur, mendengkur, hiperaktif, mengantuk pada siang hari, dan kadang-kadang enuresis. Diagnosis OSAS secara definitif menggunakan polisomnografi yaitu adanya indeks apnea atau hipopnea lebih dari 5 . Sebagai alternatif diagnosis adalah menggunakan kuesioner Brouillette dkk, observasi dengan video, atau menggunakan pulse oksimetri. Tata laksana OSAS pada anak adalah pengangkatan adenoid (adenoidektomi dan/atau tonsilektomi). Angka keberhasilannya cukup tinggi yaitu sekitar $75 \%$. Selain itu diet untuk penurunan berat badan pada obesitas, serta pengunaan CPAP (continuous positive airway pressure). Komplikasi yang dapat terjadi adalah gangguan tingkah laku, kelainan kardiovaskular, dan gagal tumbuh.
\end{abstract}

Kata kunci: OSAS, anak, diagnosis, adenoidektomi, tonsilektomi

$C$ 7 idur merupakan kebutuhan utama bagi anak yang berfungsi sebagai restorasi dan homeostasis seluruh sistem organ tubuh. Tidak jarang seseorang mengalami gangguan tidur, dari gangguan ringan sampai berat seperti sulit tidur, mendengkur (snoring) sampai yang sangat kompleks seperti sleep apnea syndrome. ${ }^{1}$

Obstructive sleep apnea syndrome (OSAS) merupakan salah satu bagian dari OAS. Pertama kali dilaporkan oleh Guillenimault dkk pada tahun 1976 pada 8 orang anak berusia 5 - 14 tahun berdasarkan manifestasi klinis dan polisomnografi. ${ }^{2}$ Setelah dilaporkan adanya OSAS pada anak, beberapa ahli mulai meneliti lebih jauh tentang OSAS pada anak.

Alamat Korespondensi:

Dr. Bambang Supriyatno Sp.A(K)

Divisi Respirologi Departemen Ilmu Kesehatan Anak FKUI-RSCM, Jakarta 10430.

Telepon: 021-3100669. Fax.021-390 7743
Kecurigaan adanya OSAS ditandai dengan ditemukannya mendengkur (snoring) pada anak. Prevalensi mendengkur pada anak sekitar 3,2-12,1\%, sedangkan prevalensi OSAS 0,7 - 10,3\%. Adanya perbedaan yang cukup besar bergantung kepada metode yang digunakan. Dapat digunakan polisomnografi (PSG) sebagai alat diagnosis baku emas untuk OSAS dan ada yang tidak menggunakan, demikian pula penggunaan definisi mendengkur yang berbeda. ${ }^{3}$

Faktor risiko OSAS pada anak sangat berbeda dengan orang dewasa. ${ }^{4}$ Pada dewasa, obesitas merupakan faktor risiko utama terjadinya OSAS, sedangkan pada anak meskipun merupakan faktor risiko tetapi bukan merupakan yang utama.

\section{Definisi}

Sleep apnea syndrome adalah suatu sindrom dengan ditemukannya episode apnea atau hipopnea pada saat 
tidur. Apnea dapat disebabkan kelainan sentral, obstruktif jalan nafas, atau campuran. Obstruktif apnea adalah berhentinya aliran udara pada hidung dan mulut walaupun dengan usaha nafas, sedangkan central apnea adalah penghentian pernafasan yang tidak disertai dengan usaha bernafas akibat tidak adanya rangsangan nafas. Obstruktif hipoventilasi disebabkan oleh obstruksi parsial aliran udara yang menyebabkan hipoventilasi dan hipoksia. Istilah obstruktif hipoventilasi digunakan untuk menunjukkan adanya hipopnea, yang berarti adanya pengurangan aliran udara.

Istilah OSAS dipakai pada sindrom obstruksi total atau parsial jalan nafas yang menyebabkan gangguan fisiologis yang bermakna dengan dampak klinis yang bervariasi. Istilah primary snoring (mendengkur primer) digunakan untuk menggambarkan anak dengan kebiasaan mendengkur yang tidak berkaitan dengan obstruktif apnea, hipoksia atau hipoventilasi. ${ }^{1,5}$ Guilleminault dkk mendefinisikan sleep apnea sebagai episode apnea sebanyak 30 kali atau lebih dalam 8 jam, lamanya paling sedikit 10 detik dan terjadi baik selama fase tidur rapid eye movement (REM) dan non rapid eye movement (NREM). ${ }^{2}$ Terdapat istilah apnea index (AI) dan hypopnea index (HI) yaitu frekuensi apnea atau hipopnea per jam. Apnea atau hypopnea index dapat digunakan sebagai indikator berat ringannya OAS. ${ }^{3}$

\section{Epidemiologi}

Secara epidemiologi, OSAS lebih sering terjadi pada orang dewasa daripada anak-anak. Mendengkur karena kebiasaan, dijumpai pada masa anak-anak yang terjadi pada $7-9 \%$ dari anak-anak pra sekolah dan anak usia sekolah. ${ }^{6}$ Schechter, ${ }^{3}$ mendapatkan prevalensi snoring berkisar antara 3,2-12,1\% bergantung kriteria inklusi yang dipakai. Gangguan pernafasan selama tidur didapat pada kira-kira 0,7-10,3\% dari anak-anak berusia 4 - 5 tahun. ${ }^{7,8}$ Kejadian OSAS terjadi pada anak semua umur termasuk neonatus. ${ }^{8}$

Pada masa neonatus insidens apnea kira-kira 25\% pada bayi dengan berat badan lahir < 2500 gram dan $84 \%$ pada bayi dengan berat badan lahir $<1000$ gram. ${ }^{9}$ Insidens tertinggi terjadi antara umur 3 - 6 tahun karena pada usia ini sering terjadi hipertrofi tonsil dan adenoid. Pada anak, kejadian OSAS tidak berhubungan dengan jenis kelamin, sedangkan pada dewasa lelaki lebih sering dibandingkan perempuan yaitu sekitar
8:1. ${ }^{4}$ Terdapat kecenderungan familial untuk terjadinya OSAS. ${ }^{7}$ Yoshizuwa dkk di Jepang menggambarkan hubungan antara OSAS dan tipe HLA - A2 yang spesifik. ${ }^{10}$ Prevalensi OSAS pada kelompok etnik yang berbeda tidak diketahui. ${ }^{1}$

\section{Patogenesis}

Patogenesis OSAS pada anak belum banyak diketahui; terjadi jika didapatkan gangguan antara faktor yang mempertahankan patensi saluran nafas dan komponen jalan nafas bagian atas (misalnya ukuran anatomis) yang menyebabkan kolapsnya jalan nafas. Faktor-faktor yang memelihara patensi saluran nafas adalah a) respons pusat ventilasi terhadap hipoksia, hiperkapnia, dan sumbatan jalan nafas; b) efek pusat rangsangan dalam meningkatkan tonus neuromuskular jalan nafas bagian atas; c) efek dari keadaan tidur dan terbangun.

Terdapat dua teori patofisiologi sumbatan (kolaps) jalan nafas yaitu, ${ }^{1,5}$

1. Teori balance of forces: ukuran lumen farings tergantung pada keseimbangan antara tekanan negatif intrafaringeal yang timbul selama inspirasi dan aksi dilatasi otot-otot jalan nafas atas. Tekanan transmural pada saluran nafas atas yang mengalami kolaps disebut closing pressure. Dalam keadaan bangun, aktivasi otot jalan nafas atas akan mempertahankan tekanan tranmural di atas closing pressure sehingga jalan nafas atas tetap paten. Pada saat tidur tonus neuromuskular berkurang, akibat lumen farings mengecil sehingga menyebabkan aliran udara terbatas atau terjadi obstruksi.

2. Teori starling resistor: jalan nafas atas berperan sebagai starling resistor yaitu perubahan tekanan yang memungkinkan farings untuk mengalami kolaps yang menentukan aliran udara melalui saluran nafas atas.

Faktor-faktor yang mempengaruhi tekanan intraluminal maupun fungsi otot saluran nafas atas yang mempermudah terjadinya kolaps jalan nafas selama tidur telah diketahui. Manifestasi OSAS timbul jika faktor yang menyebabkan peningkatan resistensi jalan nafas bergabung dengan kelainan kontrol susunan saraf pusat terhadap fungsi otot-otot saluran nafas atas. Kemungkinan kombinasi faktor-faktor ini dapat menerangkan mengapa beberapa anak dengan kelainan 
struktur mengalami OSAS sementara yang lainnya dengan derajat penyempitan saluran nafas yang sama menunjukkan pernafasan yang normal selama tidur.

\section{Faktor Risiko}

Faktor risiko terjadinya OSAS pada anak antara lain sebagai akibat hipertrofi adenoid dan tonsil, disproporsi kraniofasial, obesitas. ${ }^{1-4}$ Hipertrofi adenoid dan tonsil merupakan keadaan yang paling sering menyebabkan OSAS pada anak. Ukuran adenoid dan tonsil tidak berbanding lurus dengan berat ringannya OSAS. Terdapat anak dengan hipertrofi adenoid yang cukup besar, namun OSAS yang terjadi masih ringan, anak lain dengan pembesaran adenoid ringan menunjukkan gejala OSAS yang cukup berat. Hipertrofi adenoid dan tonsil dapat juga menyebabkan penyulit pada anak dengan kelainan dasar tulang. Walaupun pada sebagian besar anak OSAS membaik setelah dilakukan adenotonsilektomi, namun sebagian kecil akan menetap setelah dioperasi. Pada suatu penelitian sebagian kecil anak dengan OSAS yang telah berhasil diatasi dengan operasi adenotonsilektomi kemudian mengalami rekurensi gejalanya selama masa remaja. ${ }^{2,3}$ Anak dengan anomali kraniofasial yang mengalami penyempitan struktur saluran nafas yang nyata (mikrognasi dan midface hypoplasia) akan mengalami OSAS. Pada anak dengan disproporsi kraniofasial dapat menyebabkan sumbatan saluran nafas meskipun tanpa disertai hipertrofi adenoid. 1,4,10

Salah satu penyebab OSAS yang lain adalah obesitas. Pada dewasa obesitas merupakan penyebab utama OSAS sedangkan pada anak obesitas bukan sebagai penyebab utama. Mekanisme terjadinya OSAS pada obesitas karena terdapat penyempitan saluran nafas bagian atas akibat penimbunan jaringan lemak di dalam otot dan jaringan lunak di sekitar saluran nafas, maupun kompresi eksternal leher dan rahang. ${ }^{2,4,11,12}$ Penentuan obesitas dapat dilakukan dengan cara menghitung body mass index (BMI) dan pengukuran lingkar leher. Untuk penentuan OSAS, yang lebih berperan adalah lingkar leher dibandingkan dengan BMI. ${ }^{12}$ Telah diketahui bahwa lingkar leher yang besar atau obesitas pada daerah atas berhubungan dengan peningkatan penyakit kardiovaskular, demikian pula diduga berhubungan dengan mendengkur dan OSAS. Diduga bahwa penumpukan lemak pada daerah leher dapat membuat saluran nafas atas menjadi lebih sempit. Kemungkinan lain adalah pada pasien obesitas dengan leher yang besar mempunyai velofarings yang lebih mudah mengalami kolaps sehingga dapat mempermudah terjadinya sumbatan saluran nafas atas pada waktu tidur. ${ }^{12,13}$

\section{Patofisiologi}

Pasien dengan OSAS mampu mempertahankan patensi saluran nafas bagian atas selama bangun/tidak tidur, karena peningkatan tonus otot saluran nafas akibat input dari pusat kortikal yang lebih tinggi. Namun selama tidur kolaps jalan nafas bagian atas terjadi pada saat inspirasi dan kadang-kadang meningkatkan usaha bernafas. Pada anak lebih sering mengalami periode obstruksi parsial saluran nafas yang berkepanjangan dan hipoventilasi dibandingkan orang dewasa. ${ }^{1,5}$

Keadaan apnea lebih jarang pada anak dan umumnya waktu lebih singkat daripada orang dewasa. Hipoksia dan hiperkapnia terjadi akibat siklus obstruksi parsial atau total. Obstruktif apnea menyebabkan peningkatan aktifitas otot-otot dilatator saluran nafas atas sehingga mengakibatkan berakhirnya apnea. Pada anak dengan OSAS arousal jauh lebih jarang, dan obstruksi parsial dapat berlangsung terus selama berjam-jam tanpa terputus.

\section{Manifestasi klinis}

Manifestasi klinis yang terbanyak adalah kesulitan bernafas pada saat tidur yang biasanya berlangsung perlahan-lahan. Sebelum gejala kesulitan bernafas terjadi, mendengkur merupakan gejala yang mulamula timbul. Dengkuran pada anak dapat terjadi secara terus menerus (setiap tidur) ataupun hanya pada posisi tertentu saja. Pada OSAS, pada umumnya anak mendengkur setiap tidur dengan dengkuran yang keras terdengar dari luar kamar dan terlihat episode apnea yang mungkin diakhiri dengan gerakan badan atau terbangun Sebagian kecil anak tidak memperlihatkan dengkur yang klasik, tetapi berupa dengusan atau hembusan nafas, noisy breathing (nafas berbunyi). Usaha bernafas dapat terlihat dengan adanya retraksi. Posisi pada saat tidur biasanya tengkurap, setengah duduk, atau hiperekstensi leher untuk mempertahankan patensi jalan nafas. ${ }^{1,4,14}$ 
Pada pemeriksaan fisis dapat terlihat pernafasan melalui mulut, adenoidal facies, midfacial hypoplasia, retro/mikrognasi atau kelainan kraniofasial lainnya, obesitas, gagal tumbuh, stigmata alergi misalnya alergic shiners atau lipatan horizontal hidung. ${ }^{15}$ Patensi pasase hidung harus dinilai, perhatikan adanya septum deviasi atau polip hidung, ukuran lidah, integritas palatum, daerah orofarings, redudant mukosa palatum, ukuran tonsil, dan ukuran uvula, mungkin ditemukan pectus excavatum. Paru-paru biasanya normal pada pemeriksaan auskultasi. Pemeriksaan jantung dapat memperlihatkan tanda-tanda hipertensi pulmonal misalnya peningkatan komponen pulmonal bunyi jantung II, pulsasi ventrikel kanan. Pemeriksaan neorologis harus dilakukan untuk mengevaluasi tonus otot dan status perkembangan. ${ }^{16}$

\section{Diagnosis}

\section{A. Polisomnografi}

Cara definitif untuk menegakkan diagnosis OSAS dengan pemeriksaan polisomnografi pada saat tidur. Polisomnografi merupakan pemeriksaan baku emas untuk menegakkan diagnosis OSAS. Pada anak, tanda dan gejala obstructive sleep apnea lebih ringan dari pada orang dewasa; karena itu diagnosisnya lebih sulit dan harus dipertegas dengan polisomnografi. Polisomnografi juga akan menyingkirkan penyebab lain dari gangguan pernafasan selama tidur. Pemeriksaan ini memberikan pengukuran yang objektif mengenai beratnya penyakit dan dapat digunakan sebagai data dasar untuk mengevaluasi keadaannya setelah operasi. ${ }^{17}$

\section{B. Uji tapis}

Mengingat bahwa polisomnografi memerlukan waktu, biaya yang mahal, dan belum tentu tersedia di fasilitas kesehatan, maka diperlukan suatu metode lain sebagai uji tapis. Uji tapis yang banyak digunakan adalah dengan menggunakan kuesioner. Brouillette $\mathrm{dkk}^{17}$ menunjukkan bahwa penelitian tidur yang abnormal dapat diprediksi dengan suatu questionnare score yang disebut skor OSAS.

$$
\text { Skor OSAS }=1,42 \mathrm{D}+1,41 \mathrm{~A}+0,71 \mathrm{~S}-3,83
$$

- D: kesulitan bernafas (0: tidak pernah, 1: sekali- sekali, 2: sering, 3: selalu)

- A: apnea (0: tidak ada, 1: ada)

- $S$ : snoring (mendengkur) (0: tidak pernah, 1 : sekali-sekali, 2: sering, 3: selalu)

Dengan rumus di atas, ditentukan kemungkinan OSAS berdasarkan nilai:

- $\quad$ Skor < -1 : bukan OSAS

- $\quad$ Skor -1 sampai 3,5 mungkin OSAS mungkin bukan OSAS

- $\quad$ Skor > 3,5 sangat mungkin OSAS

Dengan menggunakan skor di atas, dapat diprediksi kemungkinan OSAS meskipun tetap memerlukan pemeriksaan polisomnografi. Artinya meskipun skor $>3,5$ untuk diagnosis pasti tetap memerlukan polisomnografi. Beberapa peneliti dapat menerima penggunaan skor tersebut, tetapi banyak pula yang tidak menyetujuinya. Skoring tersebut mempunyai nilai sensitivitas $73 \%$ dan spesifisitas $83 \%$ dibandingkan dengan polisomnografi. ${ }^{17}$

\section{Observasi selama tidur}

Kejadian OSAS dapat didiagnosis dengan observasi langsung, anak di suruh tidur di tempat praktek dokter demikian pula OSAS dapat didiagnosis dengan melakukan review audiotapes/ videotapes yang dapat dilakukan di rumah. ${ }^{3,18}$ Beberapa variabel yang dinilai adalah kekerasan dan tipe inspirasi, pergerakan selama tidur, frekuensi terbangun, banyaknya apnea, retraksi, dan nafas dengan mulut. Cara tersebut mempunyai nilai sensitifitas $94 \%$, spesifisitas $68 \%$, nilai prediksi positif $83 \%$, dan nilai prediksi negatif $88 \%{ }^{3}$

Observasi selama tidur dapat dilakukan dengan menggunakan pulse oximetry. Pada saat tidur anak dipantau penurunan nilai saturasi dengan menggunakan oksimetri. Pencatatan pulse oximetry secara kontinyu selama tidur dianjurkan sebagai tes skrining dan dapat memperlihatkan desaturasi secara siklik yang menjadi karakteristik suatu OSAS, tetapi tidak akan mendeteksi pasien OSAS yang tidak berkaitan dengan hipoksia. Dengan menggunakan metode di atas nilai prediksi positif sebesar $97 \%$ dan nilai prediksi negatif 53\%. Hal ini berarti bahwa apabila terjadi penurunan saturasi selama tidur maka kemungkinan menderita OSAS cukup besar tetapi apabila tidak terdeteksi pada pemantauan dengan oksimetri maka di perlukan pemeriksaan polisomnografi. ${ }^{3}$ 
Sari Pediatri, Vol. 7, No. 2, September 2005

\section{Pemeriksaan laboratorium}

Pertanda hipoksia kronis seperti polisitemia atau peningkatan ekskresi metabolit ATP kadang-kadang digunakan sebagai indikator non spesifik OSAS. Pasien dengan hiperkapnia kronis selama tidur dapat mengalami peningkatan bikarbonat serum yang persisten akibat kompensasi alkalosis metabolik.

Beberapa jenis sitokin diketahui mempunyai efek somnogenik dan berperan penting dalam proses tidur. Interleukin-1 dan TNF- $\alpha$ dapat meningkatkan slow wave sleep dan pemberian anti TNF- $\alpha$ anti body dapat menghambat fase NREM. Irama sirkadian dari pelepasan TNF- $\alpha$ mengalami gangguan pada pasien OSAS, kadar puncak fisiologis pada malam harinya menghilang sedangkan pada siang hari kadar puncaknya meningkat. ${ }^{19}$

\section{Pengobatan}

Tatalaksana OSAS pada anak dibagi menjadi dua kelompok besar yaitu tindakan bedah dan medis (non bedah). Tindakan bedah yang dilakukan adalah tonsilektomi dan/atau adenoidektomi dan koreksi terhadap disproporsi kraniofasial, sedangkan terapi medis dapat berupa diet pada anak dengan obesitas dan pemakaian nasal CPAP (Continuous Positif Airway Pressure $).{ }^{20}$

\section{1 . Tonsilektomi dan/atau adenoidektomi}

Banyak ahli berpendapat bahwa tindakan tonsilektomi dan/atau adenoidektomi merupakan tindakan yang harus dilakukan karena keuntungannya lebih besar. Tingkat kesembuhan tindakan ini pada anak sekitar 75-100\%. ${ }^{3,21}$ Pada anak dengan etiologi hipertrofi adenoid dan tonsil saja angka keberhasilannya tinggi tetapi apabila disertai dengan risiko lain seperti obesitas dan disproporsi kraniofasial maka pascaoperasi akan tetap timbul OSAS. Meskipun demikian, karena OSAS terjadi akibat ukuran struktur komponen saluran nafas atas relatif kecil dibandingkan dengan ukuran absolut dari tonsil dan adenoid, maka para ahli berpendapat tindakan tonsilektomi dan/atau adenoidektomi tetap diperlukan pada keadaan di atas. ${ }^{22}$ Pasca tonsilektomi dan/atau adenoidektomi diperlukan pemantauan dengan polisomnografi sebagai tindak lanjut. Kadangkadang gejala masih ada dan dalam beberapa minggu kemudian menghilang. Tatalaksana non medis lainnya seperti penanganan obesitasnya tetap dilakukan meskipun telah dilakukan tonsilektomi dan/atau adenoidektomi. ${ }^{23}$

\section{Continuous positive airway pressure (CPAP)}

Nasal CPAP telah digunakan dengan hasil yang baik pada anak termasuk bayi, anak obesitas, sindrom Down, akondroplasia, dan dengan kelainan kraniofasial. Pada kelompok usia anak, CPAP terutama berguna untuk pasien yang obesitas dan pasien dengan OSAS yang menetap setelah dilakukan tonsilektomi dan/atau adenoidektomi. Sebenarnya indikasi pemberian CPAP adalah apabila setelah dilakukan tonsilektomi dan/atau adenoidektomi pasien masih mempunyai gejala OSAS atau sambil menunggu tindakan tonsilektomi dan/atau adenoidektomi. Kunci keberhasilan terapi CPAP adalah kepatuhan berobat dan hal tersebut memerlukan persiapan pasien yang baik, edukasi, dan pemantauan yang intensif. ${ }^{3,21}$

Penggunaan CPAP dengan peningkatan tekanan inspirasi secara bertahap atau dengan tekanan ekspirasi yang lebih rendah dapat meningkatkan kenyamanan pasien. Efek samping CPAP biasanya ringan dan berhubungan dengan kebocoran udara di sekitar selang masker. Keadaan ini dapat menyebabkan mata kering, konjungtivitis, dan ruam pada kulit. Dekongestan, tetes hidung dengan $\mathrm{NaCl}$ fisologis atau penggunaan sistem CPAP dengan menggunakan humidifer dapat mengurangi efek samping. ${ }^{21}$

\section{Penurunan berat badan}

Pada pasien obesitas, penurunan berat badan mutlak di lakukan. Dengan penurunan berat badan dapat menyebabkan perbaikan OSAS yang nyata. Penurunan berat badan merupakan kunci keberhasilan terapi OSAS pada anak dengan predisposisi obesitas. Sayangnya menurunkan berat badan pada anak lebih sulit dilakukan dari pada dewasa. Pendekatan yang dilakukan harus bertahap karena menurunkan berat badan secara drastis tidak dianjurkan pada anak. Perlu kesabaran dan perhatian tenaga kesehatan lebih banyak dalam yang menangani pasien dengan obesitas. Cara ideal adalah menurunkan berat badan secara perlahan dan konsisten, hal ini memerlukan waktu lama. Selain 
memperbaiki diet pada obesitas, hal yang perlu diperhatkan adalah penyakit lain yang mungkin menyertainya seperti diabetes melitus atau hipoertensi. Oleh karena itu sambil menunggu berat badan turun diperlukan pemasangan CPAP. Nasal CPAP harus digunakan sampai mencapai penurunan berat badan yang cukup. Peningkatan berat badan akan memperburuk OSAS dan penurunan berat badan dapat menurunkan gejala OSAS. Dalam hal penanganan obesitas termasuk di dalamnya adalah modfikasi perilaku, terapi diet, olah raga (exercise), dan obatobatan. ${ }^{23}$ Pada pasien OSAS yang berat dan memberi komplikasi yang potensial mengancam hidup memerlukan perawatan di rumah sakit. $3,11,18$

\section{Obat-obatan}

Obstruksi hidung merupakan faktor yang umumnya dapat mempermudah terjadinya OSAS pada anak, dan dapat diobati dengan dekongestan nasal atau steroid inhaler. ${ }^{23,24}$ Progresteron telah digunakan sebagai stimulan pernafasan pada pasien anak dengan obesity hipoventilation syndrom. Keberhasilan pemberian obatobat tersebut kurang bermakna sehingga kurang dianjurkan. Obat-obat penenang dan obat yang mengandung alkohol harus dihindarkan karena dapat memperberat OSAS.

\section{Trakeostomi}

Trakeostomi merupakan tindakan sementara pada anak dengan OSAS yang berat yang mengancam hidup, dan untuk anak yang tinggal di daerah dengan peralatan operasi tidak tersedia. ${ }^{3,22}$

\section{Komplikasi}

Komplikasi OSAS terjadi akibat hipoksia kronis nokturnal, asidosis, sleep fragmentation.

\section{Komplikasi neurobehavioral}

Komplikasi neurobehavioral terjadi akibat hipoksia kronis nokturnal dan sleep fragmentation. Rasa mengantuk pada siang hari yang berlebihan dilaporkan terjadi pada $31 \%$ - $84 \%$ anak dengan OSAS. Keluhan lain yang dapat menyertai OSAS adalah keterlambatan perkembangan, penampilan di sekolah yang kurang baik, hiperaktifitas, sikap yang agresi/hiperaktif, penarikan diri dari kehidupan sosial. Manifestasi gangguan kognitif yang lebih ringan dapat sering terjadi. Suatu penelitian menunjukkan perbaikan OSAS dapat menyebabkan perbaikan yang nyata pada fungsi kognitif. ${ }^{3}$

\section{Gagal tumbuh}

Gagal tumbuh merupakan komplikasi yang sering terjadi pada anak-anak dengan OSAS kira-kira 27 $56 \%$. Penyebab gagal tumbuh pada anak dengan OSAS adalah anoreksia, disfagia, sekunder akibat hipertrofi adenoid dan tonsil, peningkatan upaya untuk bernafas, dan hipoksia. Pertumbuhan yang cepat terjadi setelah dilakukan adenotonsilektomi. ${ }^{2-4}$

\section{Komplikasi kardiovaskular}

Hipoksia nokturnal berulang, hiperkapnia dan asidosis respiratorik dapat mengakibatkan terjadinya hipertensi pulmonal yang merupakan penyebab kematian pasien OSAS. Keadaan di atas dapat berkembang menjadi kor pulmonal. Prevalensi hipertensi pulmonal pada anak dengan OSAS tidak diketahui. Brouilette $\mathrm{dkk}^{4}$ melaporkan kor pulmonal terjadi pada 55\% dari 22 anak dengan OSAS dan Guilleminault dkk, melaporkan adanya cardio respiratory failure pada $20 \%$ dari 50 pasien. $^{2}$

\section{Enuresis}

Enuresis dapat merupakan komplikasi OSAS. Etiologinya mungkin akibat kelainan dalam regulasi hormon yang mempengaruhi cairan tubuh. Enuresis khususnya yang sekunder dapat membaik setelah obstruksi jalan nafas bagian atas dihilangkan. ${ }^{3}$

\section{Penyakit respiratorik}

Pasien dengan OSAS lebih mungkin mengaspirasi sekret dari respiratorik atas yang dapat menyebabkan kelainan respiratorik bawah dan memungkinkan terjadinya infeksi respiratorik. Keadaan ini dapat membaik setelah dilakukan tonsilektomi dan/atau adenoidektomi. Beberapa anak dengan tonsil yang besar mengalami disfagia atau merasa sering tercekik dan mempunyai risiko untuk mengalami aspirasi pneumonia. $^{3}$ 


\section{Gagal nafas dan kematian}

Laporan kasus telah melaporkan adanya gagal nafas pada pasien dengan OSAS yang berat atau akibat komplikasi perioperatif. ${ }^{3}$

\section{Kesimpulan}

- Tidur merupakan kebutuhan yang penting dari siklus kehidupan seseorang

- OSAS merupakan penyebab kesakitan yang cukup sering ditemukan pada anak

- Manifestasi klinis OSAS dapat berupa mendengkur dengan episode apnea, infeksi respiratorik berulang, gangguan belajar dan tingkah laku, mengantuk pada siang hari, gagal tumbuh, enuresis, bernapas melalui mulut, dengan atau tanpa hipertrofi tonsil dan adenoid atau kelainan kraniofasial.

- Polisomnografi merupakan pemeriksaan baku emas untuk menentukan diagnosis OSAS. Beberapa pemeriksaan seperti skor OSAS, dan pulse oximetry, dapat digunakan sebagai uji tapis.

- Tonsilektomi dan/atau adenoidektomi merupakan tatalaksana bedah yang dianjurkan pada OSAS anak disamping CPAP dan penurunan berat badan.

\section{Daftar Pustaka}

1. Marcus CL. Carroll JL. Obstructive sleep apnea syndrome. Dalam: Loughlin GM, Eiger H, penyunting. Respiratory disease in children; diagnosis and management. Baltimore, William \& Wilkins, 1994. h. 475-91.

2. Guilleminault C, Eldredge FL, Simmons B. Sleep apnea in eight children. Pediatrics 1976; 58:23-31.

3. Schechter MS, Technical report: Diagnosis and management of childhood obstructive sleep apnea syndrome. Pediatrics 2002; 109:1-20.

4. Brouillette RT, Fernbach SK, Hunt CE. Obstructive sleep apnea in infants and children. J Pediatr 1982; 100:31-9.

5. Carroll JL, Loughlei GM. Diagnostic criteria for obstructive sleep apnea syndrome in children. Pediatr Pulmonol 1992; 14:71-4.

6. Deegan MN. Clinical prediction rules in obstructive sleep apnea syndrome. Eur Respir J 1997; 10:1194-5.
7. Ali NJ. Pitson DJ, Stardling JR. The prevalence of snoring, sleep disturbance and sleep related disoders and their relation of daytime sleepiness in 4-5 year old children. Am Rev Respir Dis 1991; 143:381A.

8. Ali NJ, Pitson DJ, Stardling JR. Snoring, sleep disturbance and behavior in 4-5 year old. Arch Dis Child 1993; 68:360-6.

9. Miller MJ, Martin RJ. Apnea of prematurity. Dalam: Hunt CE, penyunting. Clinics in perinatology. Philadelphia, WB Saunders Co, 1992:789-804.

10. Yoshizawa T, Kurashina K, Sasaki I. Analysis of HLA antigens with obtructive sleep apnea syndrome. Am Rev Respir Dis 1991; 143:381A.

11. Smith RS, Ronald J, Delaive K, Walld R, Manfreda J, Kryger MH. What are obstructive sleep apnea patients being treated for prior to this diagnosis?. Chest 2002; 121:164-72.

12. Deegan PC, McNicholas WT. Pathophysiology of obstructive sleep apnoea. Dalam: McNicholas WT, penyunting. Respiratory disorders during sleep. United Kingdom, ERS J Ltd; 1998. h. 28-62.

13. PartinenM, McNicholasWT. Epidemiology, morbidity, and mortality of the seep apnoea syndrome. Dalam: McNicholas WT, penyunting. Respiratory disorders during sleep. United Kingdom, ERS J Ltd; 1998. h. 6374.

14. Neil AM, Angus SM, Sajkov D. Effects of sleep posture on upper airway stability in patients with obstructive sleep apnea. Am J Respir Crit Care Med 1997; 155:199204.

15. McColley SA, Carroll JL, Curtis S. High prevalence of allergic sensitization in children with habitual snoring and obstructive sleep apnea. Chest 1997; 111:170-3.

16. Laks L, Lehrhaft B, Grunstein RR. Pulmonary artery pressure response to hypoxia in sleep apnea. Am J Respir Crit Care Med 1997; 155:193-8.

17. Brouillette R, Hanson D, David R. A diagnostic approach to suspected obstructive sleep apnea in children. J Pediatr 1984; 105:10.

18. Moreilli A, Ladan S, Ducharme FM. Can sleep and wakefulness be distinguished in children by cardiorespiratory and videotape recordings?. Chest 1996;109:680-7.

19. Entzian P, Linnemann K. Schlaak M. Obtructive sleep apnea syndrome and circadian rhytms of hormones an cytokines. Am J Respir Crit Care Med 1996; 153:1080-6.

20. Ryan CF, Love LL. Mechanical properties of the velopharynx in obese patients with obstructive sleep apnea. Am J Respir Crit Care Med 1996; 154:806-12. 
21. Teschler H, Jones MB, Thomson AB, dkk. Automated continuo positive airway pressure titration for obstructive sleep apnea syndrome. Am J Respir Crit Care Med 1996; 154:734-40.

22. Levy P, BettegaG, Pepin JL. Surgical management options for snoring and sleep apnoea. Dalam: McNicholas WT, penyunting. Respiratory disorders during sleep. United Kingdom, ERS J Ltd; 1998. h. 205-26.
23. Montserrat JM, Ballester E, Hernands L. Overview of management options for snoring and sleep apnoea. Dalam: McNicholas WT, penyunting. Respiratory disorders during sleep. United Kingdom, ERS J Ltd; 1998. h. 144-78.

24. Demain JG, Goetz DW. Pediatric adenoidal hypertrophy and nasal airway obstructive with aqueous nasal beclomethason. Pediatrics 1995; 95(3):355-64. 